(c) American Dairy Science Association, 2003.

\title{
Milk Production, Nutrient Utilization, and Endocrine Responses to Increased Postruminal Lysine and Methionine Supply in Dairy Cows
}

\author{
L. Misciattelli, V. F. Kristensen, M. Vestergaard, \\ M. R. Weisbjerg, K. Sejrsen, and T. Hvelplund \\ Danish Institute of Agricultural Sciences \\ Department of Animal Nutrition and Physiology \\ P.O. Box 50, DK-8830 Tjele, Denmark
}

(Key words: protein utilization, insulin-like growth factor-I, bovine somatotropin, insulin)

Abbreviation key: AAT $=$ AA absorbed in the intestine, AAT-Lys = lysine absorbed in the intestine, AATLys\% = percent lysine in intestinally absorbed AA, AAT-Met $=$ methionine absorbed in the intestine, AATMet $\%=$ percent methionine in intestinally absorbed AA, DCHO = digestible carbohydrates, $\mathbf{D C F}=$ digestible crude fat, ECM = energy corrected milk, EPD = effective protein degradability, HLG = high lysine, grass silage based, HLM = high lysine, corn silage based, HMG = high methionine, grass silage based, $\mathbf{H M M}=$ high methionine, corn silage based, $\mathbf{k}_{\mathbf{A A T}}=$ efficiency of utilization of AAT for milk protein synthesis, $\mathbf{k}_{1}=$ efficiency of utilization of ME for milk synthesis, $\mathbf{L L G}=$ low lysine, grass silage based, $\mathbf{L L M}=$ low lysine, corn silage based, LMG = low methionine, grass silagebased, LMM = low methionine, corn silage-based, ME $=$ metabolizable energy, $\mathbf{P B V}=$ protein balance in the rumen, RHCHO = rapidly hydrolyzable carbohydrates.

\section{INTRODUCTION}

Ruminants, on the tissue level, need the same essential AA as nonruminants, but due to the complicated nature of the ruminant gastrointestinal tract, progress in the field of individual AA nutrition of dairy cows has only been moderate. Infusion trials have often identified Lys and Met as the first limiting AA, under a variety of different conditions (Rulquin et al., 1993). The role of His as a potentially limiting AA has also been demonstrated (Kim et al., 1999; Vanhatalo et al., 1999), as has the beneficial effect of postruminal infusion of Pro (Bruckental et al., 1991). Improved N-balance has been observed in response to postruminal infusion of Leu in lactating cows (Iburg and Lebzien, 2000), while Robinson et al. (1999) observed a tendency towards increased milk yield when infusing Ile postruminally. A range of possibly limiting AA has been identified under different feeding conditions involving postruminal infusion of AA. The present experiment was undertaken to investigate whether supplementation with commer-

Received January 24, 2002.

Accepted June 25, 2002.

Corresponding author: T. Hvelplund; e-mail: torben.hvelplund @agrsci.dk. 
cially available preparations of rumen-protected Lys or Met could elicit a production response when added to each of two rations composed from commonly occurring feeds but deliberately formulated to be low in absorbable Lys and Met, respectively. Furthermore, the purpose of the experiment was to investigate whether endocrine changes occur in response to AA manipulations. Parts of this study have been published in a preliminary form (Misciattelli et al., 1999b, 2001).

\section{MATERIALS AND METHODS}

The present experiment complied with the Danish Ministry of Justice, Law no. 382 (June 10, 1987) and Act no. 726 (September 9, 1993), regarding animal experimentation and care of animals.

\section{Animals and Management}

Sixty-four Danish Holstein-Friesian cows weighing on average $554 \mathrm{~kg}$ (SEM 7.2) at the onset of the experiment, were blocked in groups of eight on the basis of parity and expected calving date. Within blocks, the cows were assigned at random to one of eight different treatment groups for a 12 -wk trial period following a 3 -wk standardized preperiod initiated at parturition. All cows calved within a period of $73 \mathrm{~d}$ and had an average parity of $2.1(\mathrm{SD}=0.9)$. The cows were tethered in tie stalls mounted with rubber comfort mats and bedded with straw. Cows were fed at approximately 0730 and $1530 \mathrm{~h}$, had free access to water, and were milked in their tie stalls at approximately 0400 and $1600 \mathrm{~h}$.

\section{Diet Formulation}

The treatments consisted of four basal rations, two deliberately formulated to be low in absorbable Lys, one based on corn silage (LLM), and the other on grass silage (LLG). These two rations included rumen-protected Met, $13 \mathrm{~g}$ Smartamine M (Rhône Poulenc Animal Nutrition, Antony, France), to ensure an adequate basal Met level. The two other basal rations were formulated to be low in absorbable Met, one based on corn silage (LMM) and the other on grass silage (LMG). All four basal rations had a corresponding equivalent ration, differing only by inclusion of a protected source of either Lys or Met, resulting in four AA-fortified treatments: Ration LLM plus rumen-protected Lys and Met (HLM), $62 \mathrm{~g}$ of Smartamine ML. Ration LLG plus rumen protected Lys and Met (HLG), $61 \mathrm{~g}$ of Smartamine ML. Ration LMF plus rumen-protected methionine (HMM), $20 \mathrm{~g}$ of Smartamine M. Ration LMG plus rumen-protected methionine (HMG) from $20 \mathrm{~g}$ of Smarta- mine M. The treatments were, thus, pair-wise comparable, differing only in postruminal Lys or Met supply as altered by inclusion of Smartamine M or ML in the concentrate mixtures. Corn and grass silage were fed ad libitum, and the cows fed the corn silage-based rations were additionally fed $1.5 \mathrm{~kg}$ of $\mathrm{DM} / \mathrm{d}$ of clover grass hay to ensure an adequate physical structure of the diet. Vitamins and minerals were administered on a weekly basis with a dose of $150 \mathrm{~g} / \mathrm{cow}$ of a commercial vitamin mixture, "Rød Solitren" (Leo Pharmaceutical Products, Vejen, Denmark). The vitamin mixture was declared to contain: vitamin A, $3500 \mathrm{IU} / \mathrm{g}$; vitamin $\mathrm{D}_{3}$, $350 \mathrm{IU} / \mathrm{g}$; vitamin $\mathrm{E}$ ( $\alpha$-tocoferol), $11 \mathrm{~g} / \mathrm{kg}$; and sodium selenite, $20 \mathrm{mg} / \mathrm{kg}$. Concentrate mixtures are given in Table 1, and chemical composition of grass silage, corn silage, hay, and the concentrate mixtures are given in Table 2.

\section{Experimental Procedure and Sample Collection}

Animals were fed individually, and feed allocation was determined twice daily, and daily refusals were quantified at the following morning feeding. Animals were weighed on d 2 and 3 after calving, and on two consecutive days in the first and last weeks of the experiment. Additionally, BW were recorded in wk 3, 5, 7, 9 , and 11 after the onset of the experimental period, but complete datasets on BW were not obtained. Milk yield at morning and evening milking and composition of milk was recorded once weekly. Roughage and concentrates were sampled weekly and stored at $-20^{\circ} \mathrm{C}$ until chemical analysis. Dry matter was determined weekly, while chemical analyses were performed on samples composed to represent each 14-d period. Blood was sampled on three occasions: in the pretrial period (d 18 to 20 after calving), first half of the experimental period (d 35 to 42 after calving), and second half of the experimental period (d 88 to 98 after calving). Blood was sampled from v. jugularis by venepuncture, $2 \mathrm{~h}$ after the morning feeding (0930 to $1000 \mathrm{~h}$ ), using 10$\mathrm{ml} \mathrm{Na-heparinized} \mathrm{Vacutainers.} \mathrm{Blood} \mathrm{samples} \mathrm{were}$ stored on ice (less than $30 \mathrm{~min}$ ) until plasma was obtained by centrifugation at $3000 \mathrm{rpm}$ for $20 \mathrm{~min}$ at $4^{\circ} \mathrm{C}$.

\section{Sample Analysis}

Feed analysis. Dry matter content of concentrate mixtures, roughages, and refusals were determined at $80^{\circ} \mathrm{C}$ for $20 \mathrm{~h}$ in a forced-air oven. The DM in all other samples was determined by oven drying at $100^{\circ} \mathrm{C}$. Samples for nylon bag analysis were ground through a 1.5$\mathrm{mm}$ screen before incubation; all other samples were ground through a 1-mm screen on a laboratory mill prior to analysis. Ash was determined after combustion 
Table 1. Composition of concentrate mixtures ( $\mathrm{kg} / 1000 \mathrm{~kg}$ feed). Low Lys concentrate for grass silagebased ration (LLG), low Lys concentrate for corn silage-based rations (LLM), HLG and HLM correspond to LLG and LLM, supplemented with rumen-protected Lys. Low Met concentrate for grass silage-based ration (LMG), low Met concentrate for corn silage-based rations (LMM), HMG and HMM correspond to LMG and LMM, supplemented with rumen-protected Met.

\begin{tabular}{|c|c|c|c|c|c|c|c|c|}
\hline & LLG & HLG & LMG & HMG & LLM & HLM & LMM & HMM \\
\hline Corn gluten meal & 75 & 75 & & & 54 & 54 & & \\
\hline Rape seed cake & & & & & 286 & 286 & 166 & 164 \\
\hline Sunflower meal, decorticated & 164 & 164 & & & 115 & 115 & & \\
\hline Rape seed & 63 & 63 & 99 & 98 & & & 79 & 78 \\
\hline Barley & 618 & 614 & 472 & 475 & 457 & 453 & 88 & 95 \\
\hline Soybean meal & & & & & & & 236 & 234 \\
\hline Soypass $^{1}$ & & & 204 & 202 & & & 62 & 61 \\
\hline Peas (Pisum sativum) & & & 137 & 136 & & & 285 & 283 \\
\hline Beet molasses & 69 & 69 & 70 & 69 & 69 & 69 & 70 & 69 \\
\hline Limestone, ground & 10 & 10 & 9 & 9 & 12 & 12 & 14 & 14 \\
\hline Urea & & & & & 6 & 6 & & \\
\hline Mineral premix ${ }^{2}$ & & & 9 & 9 & & & & \\
\hline Smartamine $\mathrm{M}^{3}$ & 0.96 & & & 1.82 & 0.96 & & & 1.82 \\
\hline Smartamine $\mathrm{ML}^{3}$ & & 4.80 & & & & 4.80 & & \\
\hline
\end{tabular}

\footnotetext{
${ }^{1}$ Xylose-treated soybean meal, Borregård Lignotech, Sarpsborg, Norway.

${ }^{2}$ One kg contained: $60 \mathrm{~g}$ of Ca, $100 \mathrm{~g}$ of $\mathrm{P}, 120 \mathrm{~g}$ of $\mathrm{Mg}, 50 \mathrm{~g}$ of Na, $80 \mathrm{~g}$ of Cl, $0.5 \mathrm{~g}$ of S, $4 \mathrm{~g}$ of Fe, $4.5 \mathrm{~g}$ of $\mathrm{Zn}, 0.9 \mathrm{~g}$ of $\mathrm{Cu}, 25 \mathrm{mg}$ of $\mathrm{Co}$ and $20 \mathrm{mg}$ of Se.

${ }^{3}$ Rumen-protected Met or Met and Lys, Rhône Poulenc Animal Nutrition, Antony, France.
}

at $525^{\circ} \mathrm{C}$ for $6 \mathrm{~h}$ according to $\mathrm{AOAC}$ (1990). Nitrogen was determined by the Kjeldahl method on an automated Kjel-Foss apparatus (Foss Electric, Hillerød, Denmark) according to AOAC (1990). Crude fat was determined gravimetrically as the mass extractable in petroleum ether in a Soxhlet-apparatus, after an initial hydrolysis in $3 \mathrm{M} \mathrm{HCl}$, essentially as described by Stoldt (1952). Crude fiber was determined as outlined by Tecator (1978). Rapidly hydrolyzable carbohydrates (RHCHO) were analyzed by the method proposed by Jacobsen (1981), which involves a short gelatinization step, an incubation with amyloglucosidase and saccharase (1330 and 7684, Merck KGAa, Darmstadt, Germany) in a buffer and subsequent centrifugation, protein precipitation, and spectrofotometrical quantification of the reducing sugars after oxidation with ferricyanide. Free sugars were determined with the same method but omitting the initial gelatinization and enzyme incubation.

Digestible OM of forages was determined by incubation with rumen fluid and subsequent $\mathrm{HCl}$ and pepsin incubation as described by Tilley and Terry (1963). Enzymatically digestible $\mathrm{OM}$ of the concentrates were determined with a two-step method involving an initial $\mathrm{HCl}$ and pepsin incubation and a subsequent incubation with an array of cellulases as described by Weisbjerg and Hvelplund (1993).

Two distinct procedures were used for the analysis of AA in feeds; AA in blood and milk were not analyzed. All AA with the exception of Trp were assayed on a Biochrom B20 (LKB Biochrom, Ltd., Cambridge, England) automated AA analyzer using ninhydrin as re- agent and running in conjunction with a S200 autosampler (Perkin Elmer, Foster City, CA). Hydrolysates were prepared as described by Mason et al. (1980) with an initial 16-h oxidation of the sample in performic acid and subsequent hydrolysis in $6 \mathrm{M} \mathrm{HCl}$ at $90^{\circ} \mathrm{C}$ for $23 \mathrm{~h}$ under constant reflux. Due to the oxidation, Met was detected as methionine sulfone and Cys as cystic acid. Tyr was quantified on hydrolysates, where the oxidation step was omitted. The determined concentrations of Ser, Ile, and Val were multiplied by a factor of 1.06 to correct for losses during hydrolysis. Trp was quantified after alkaline hydrolysis of the sample in sealed tubes with $4.2 \mathrm{~N} \mathrm{NaOH}$ at $110^{\circ} \mathrm{C}$ for $16 \mathrm{~h}$ in an autoclave. The separation was performed on a S410LC HPLCapparatus (Perkin Elmer) fitted with a hypersil ODS 3- $\mu \mathrm{m}$ C-18 column (Waters, Milford, MA) and a LS-1 LC fluorescence detector, using 5-methyl-tryptophan as internal standard, as described by Bech-Andersen (1991). All integration was performed using the Turbochrom software packet (Hewlett Packard). All reference to concentrations of AA is given as grams of AA, including water, unless otherwise stated. Total AA-N was calculated as the sum of $\mathrm{N}$ in the determined proteinogenic AA, thus excluding Orn. Because Gln and Asn are converted to Glu and Asp during acid hydrolysis, only Glu and Asp were used in the calculations.

Milk analysis. Milk fat, lactose, and protein were determined by IR on a Milkoscan 104 (Foss Electric, Hillerød, Denmark) on samples of individual cows morning and evening milk pooled on a proportional volume basis. Milk composition was determined on 
Table 2. Chemical composition of grass silage (GSI), corn silage (MSI), grass hay (GHA), and concentrate mixtures: Low Lys concentrate for grass silage-based ration (LLG), low Lys concentrate for corn silage-based rations (LLM), HLG and HLM correspond to LLG and LLM, supplemented with rumen-protected Lys. Low Met concentrate for grass silage-based ration (LMG), low Met concentrate for corn silagebased rations (LMM), HMG and HMM correspond to LMG and LMM, supplemented with rumen-protected Met. Not determined (n.d.).

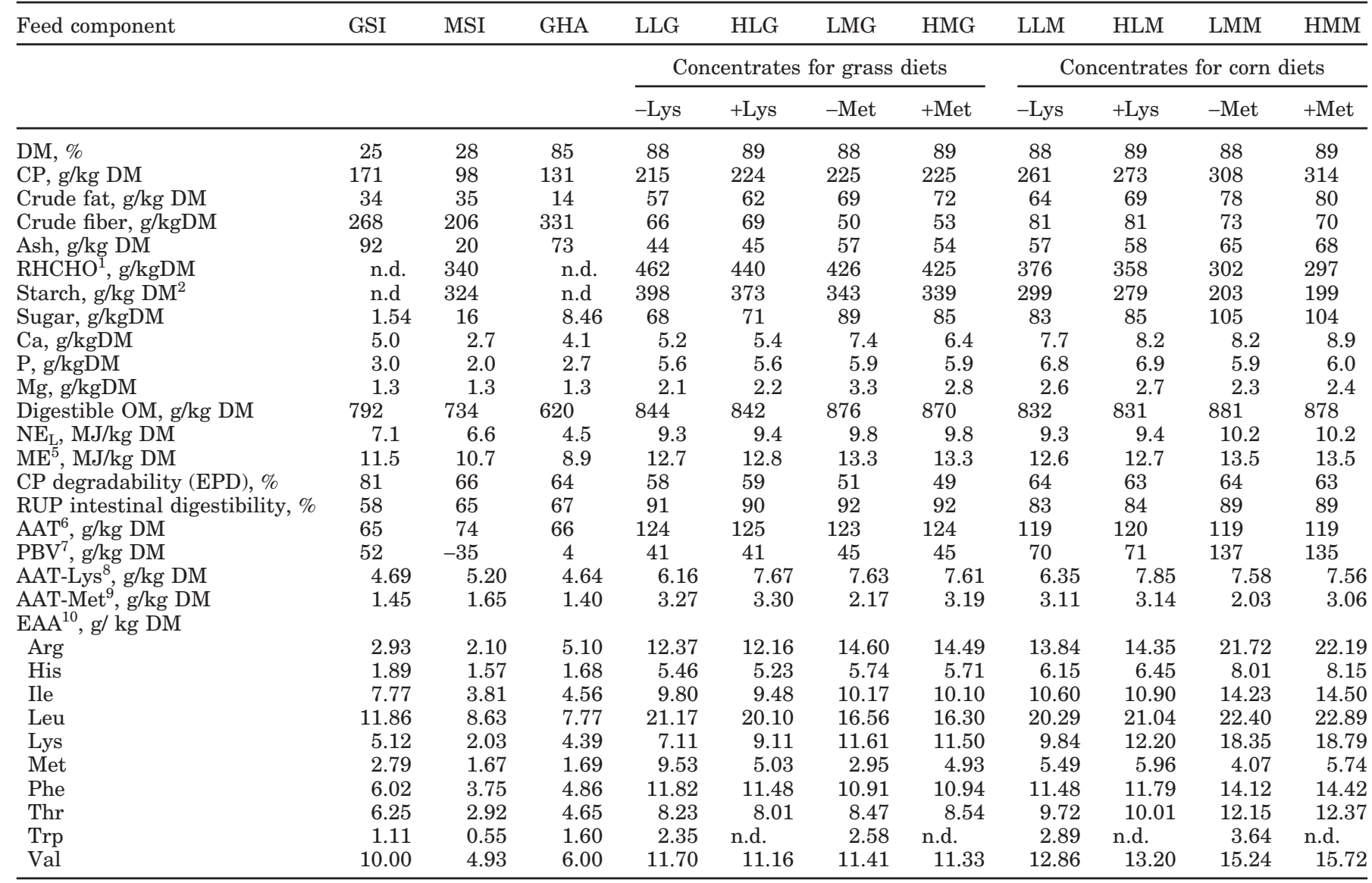

${ }^{1} \mathrm{RHCHO}=$ Rapidly hydrolyzable carbohydrates.

${ }^{2}$ Calculated as difference between RHCHO and sugar.

${ }^{5} \mathrm{ME}=$ Metabolizable energy.

${ }^{6} \mathrm{AAT}=$ Amino acids absorbed in the intestine.

${ }^{7} \mathrm{PBV}=$ Protein balance in the rumen.

${ }^{8}$ AA-Lys $=$ Lys absorbed in the intestine.

${ }^{9} \mathrm{AAT}-\mathrm{Met}=$ Met absorbed in the intestine.

${ }^{10} \mathrm{EAA}=$ Essential AA.

three samples per cow in the pretrial period and 12 samples per cow from the trial period.

Plasma metabolite analysis. Plasma metabolite concentrations were determined colorimetrically on an autoanalyzer: opeRA, clinical chemistry system (Bayer Diagnostics, Tarrytown, NY) with a commercial kit for glucose (Bayer, 1996a), a commercial kit for urea (Bayer, 1996b), and a modified commercial kit for NEFA (Wako Chemicals GmbH, Germany).

Plasma hormone analysis. Both bST and insulin were assayed using TR-IFMA (time-resolved immunofluorometric assays) and an AutoDELFIA fluorometer (Wallac, Turku, Finland). Determination of bST was in a sandwich setup by two monoclonal antibodies, developed against synthetic bST (Løvendahl et al., 2000), the intraassay CV for low (4 ng/ml), medium (14 ng/ $\mathrm{ml}$ ), and high (49 $\mathrm{ng} / \mathrm{ml})$ bST controls was 3 to $10 \%$, the interassay CV (four assays) was 1 to $9 \%$. Insulin was determined with a modified DELFIA kit (Wallac) developed against human insulin (Løvendahl and Purup, 2002), the intraassay CV for low (22 pmol/L), medium ( $88 \mathrm{pmol} / \mathrm{L})$, and high $(575 \mathrm{pmol} / \mathrm{L})$ insulin controls was 3 to $8 \%$, and the interassay CV (four assays) was 2 to $3 \%$. Details on the modifications introduced in the insulin assay can be found in Ingvartsen et al. (1999). Samples for IGF-I analysis were assayed with 
Table 3. Effect of Lys level on DMI, BW, weight gain, milk yield, and composition. Treatments were: low Lys concentrate and grass silage (LLG), high Lys concentrate and grass silage (HLG), low Lys concentrate and corn silage (LLM), and high Lys concentrate and corn silage (HLM).

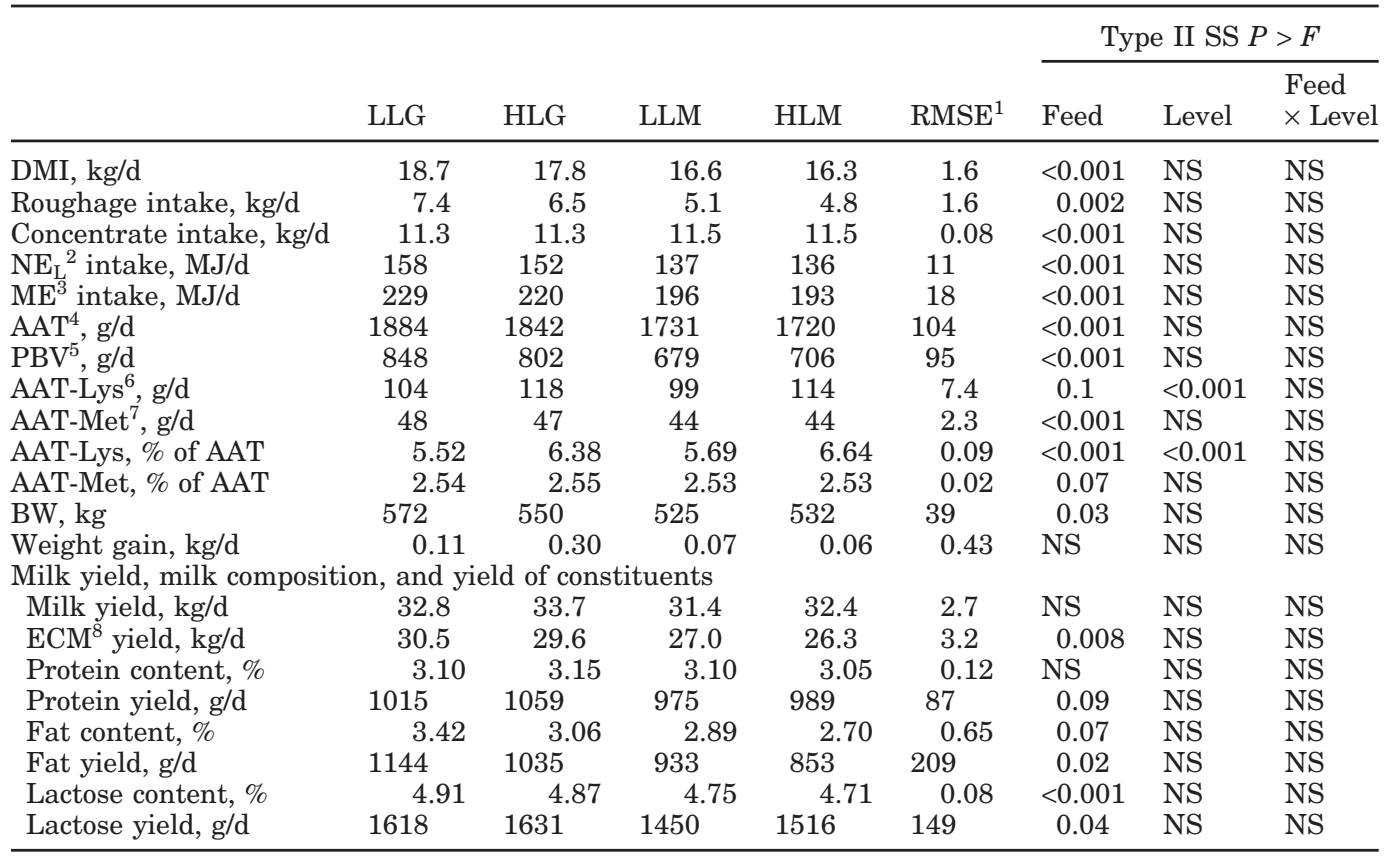

${ }^{1} \mathrm{RMSE}=$ Residual mean squares error.

${ }^{2} \mathrm{NE}_{\mathrm{L}}=$ Net energy for lactation.

${ }^{3} \mathrm{ME}=$ Metabolizable energy.

${ }^{4} \mathrm{AAT}=$ Amino acids absorbed in the intestine.

${ }^{5} \mathrm{PBV}=$ Protein balance in the rumen.

${ }^{6}$ AAT-Lys $=$ Lys absorbed in the intestine.

${ }^{7} \mathrm{AAT}-\mathrm{Met}=$ Met absorbed in the intestine.

${ }^{8} \mathrm{ECM}=$ Energy corrected milk $(3.14 \mathrm{MJ} / \mathrm{kg})$.

a noncompetitive TR-IFMA (Frystyk et al., 1995), by use of a DELFIA 1234, research fluorometer (Wallac). The intraassay CV for low ( $84 \mathrm{ng} / \mathrm{ml}$ ) and high (164 ng/ ml) IGF-I controls was 5 to $6 \%$, and the interassay CV (nine assays) was 6 to $7 \%$.

\section{Calculations}

Body weight gain was estimated from linear regression analysis of weight data for each individual cow, and mean BW was calculated as the BW in mid trial period by the obtained equation.

The AA absorbed in the small intestine (AAT) and the protein balance in the rumen (PBV) were calculated according to the system described by Madsen et al. (1995), utilizing data on effective protein degradability (EPD) and intestinal digestibility of RUP of individual feed components obtained from in situ incubations and corrected for loss of small particles according to Hvelplund and Weisbjerg (2000). Microbial N synthesized was calculated as $29 \mathrm{~g} / \mathrm{kg}$ carbohydrate digested in the total tract (DCHO, Hvelplund and Madsen, 1985). The DCHO was calculated by the following formula:

$$
\mathrm{DCHO}=\text { digestible } \mathrm{OM}-(\text { digestible } \mathrm{CP}+\mathrm{DCF}),
$$

where digestible OM values were the corrected figures from the in vitro digestibility analysis as described by Weisbjerg and Hvelplund (1993) and Møller et al. (1989), and digestible CP was calculated from the percentage of CP in DM by the equation proposed by Thomsen (1979). Digestible crude fat (DCF) was calculated from the percentage of crude fat, by the equation proposed by Weisbjerg et al. (1991). Intestinally absorbed Lys (AAT-Lys) and Met (AAT-Met) were also calculated based on in sacco estimates of rumen degradability and intestinal digestibility of $\mathrm{CP}$ in conjunction with AA analysis on the individual feed components (Misciattelli et al., 2002), assuming that $\mathrm{CP}$ values also could be applied on individual AA. The Lys and Met proportions in RUP was assumed equivalent to the content of Lys and Met in the original protein expressed as: grams 
Table 4. Effect of Met level on DMI, BW, weight gain, milk yield, and composition. Treatments were: low Met concentrate and grass silage (LMG), high Met concentrate and grass silage (HMG), low Met concentrate and corn silage (LMM), and high Met concentrate and corn silage (HMM).

\begin{tabular}{|c|c|c|c|c|c|c|c|c|}
\hline & \multirow[b]{2}{*}{ LMG } & \multirow[b]{2}{*}{ HMG } & \multirow[b]{2}{*}{ LMM } & \multirow[b]{2}{*}{ HMM } & \multirow[b]{2}{*}{ RMSE1 } & \multicolumn{3}{|c|}{ Type II SS $P<F$} \\
\hline & & & & & & Feed & Level & $\begin{array}{l}\text { Feed } \\
\times \text { Level }\end{array}$ \\
\hline DMI, kg/d & 19.4 & 18.7 & 17.3 & 17.1 & 1.6 & 0.004 & NS & NS \\
\hline Roughage intake, kg/d & 9.4 & 8.7 & 7.5 & 7.1 & 1.6 & 0.005 & NS & NS \\
\hline Concentrate intake, $\mathrm{kg} / \mathrm{d}$ & 9.8 & 10.0 & 10.0 & 9.9 & 0.08 & NS & 0.03 & 0.02 \\
\hline $\mathrm{NE}_{\mathrm{L}}^{2}$ intake, MJ/d & 164 & 159 & 148 & 147 & 11 & 0.002 & NS & NS \\
\hline $\mathrm{ME}^{3}$ intake, $\mathrm{MJ} / \mathrm{d}$ & 241 & 233 & 209 & 207 & 18 & $<0.001$ & NS & NS \\
\hline $\mathrm{AAT}^{4}, \mathrm{~g} / \mathrm{d}$ & 1839 & 1800 & 1712 & 1703 & 113 & 0.01 & NS & NS \\
\hline $\mathrm{PBV}^{5}, \mathrm{~g} / \mathrm{d}$ & 938 & 900 & 1147 & 1159 & 84 & $<0.001$ & NS & NS \\
\hline AAT-Lys $^{6}$, g/d & 120 & 117 & 113 & 112 & 8.0 & 0.04 & NS & NS \\
\hline AAT-Met ${ }^{7}, \mathrm{~g} / \mathrm{d}$ & 35 & 44 & 32 & 42 & 2.5 & 0.004 & $<0.001$ & NS \\
\hline AAT-Lys, $\%$ of AAT & 6.54 & 6.47 & 6.57 & 6.56 & 0.04 & $<0.001$ & 0.005 & 0.08 \\
\hline AAT-Met, $\%$ of AAT & 1.92 & 2.47 & 1.86 & 2.46 & 0.02 & 0.001 & $<0.001$ & 0.005 \\
\hline BW, kg & 558 & 555 & 563 & 554 & 43 & NS & NS & NS \\
\hline Weight gain, kg/d & 0.20 & 0.13 & -0.02 & -0.10 & 0.40 & NS & NS & NS \\
\hline \multicolumn{9}{|c|}{ Milk yield, milk composition, and yield of constituents } \\
\hline Milk yield, kg/d & 36.3 & 34.2 & 30.6 & 30.9 & 3.1 & $<0.001$ & NS & NS \\
\hline $\mathrm{ECM}^{8}$ yield, $\mathrm{kg} / \mathrm{d}$ & 33.8 & 34.0 & 29.4 & 30.3 & 2.7 & $<0.001$ & NS & NS \\
\hline Protein content, $\%$ & 2.97 & 3.18 & 2.94 & 3.08 & 0.14 & NS & 0.002 & NS \\
\hline Protein yield, g/d & 1070 & 1090 & 905 & 945 & 83 & $<0.001$ & NS & NS \\
\hline Fat content, \% & 3.58 & 3.93 & 3.89 & 4.01 & 0.31 & 0.10 & 0.04 & NS \\
\hline Fat yield, g/d & 1292 & 1354 & 1192 & 1229 & 114 & 0.01 & NS & NS \\
\hline Lactose content, \% & 4.99 & 4.90 & 4.82 & 4.81 & 0.12 & 0.006 & NS & NS \\
\hline Lactose yield, g/d & 1802 & 1683 & 1472 & 1491 & 177 & $<0.001$ & NS & NS \\
\hline
\end{tabular}

${ }^{1} \mathrm{RMSE}=$ Residual mean squares error

${ }^{2} \mathrm{NE}_{\mathrm{L}}=$ Net energy for lactation.

${ }^{3} \mathrm{ME}=$ Metabolizable energy.

${ }^{4} \mathrm{AAT}=$ Amino acids absorbed in the intestine.

${ }^{5} \mathrm{PBV}=$ Protein balance in the rumen .

${ }^{6}$ AAT-Lys $=$ Lys absorbed in the intestine.

${ }^{7}$ AAT-Met $=$ Met absorbed in the intestine

${ }^{8} \mathrm{ECM}=$ Energy corrected milk $(3.14 \mathrm{MJ} / \mathrm{kg})$.

AA (excl. $\left.\mathrm{H}_{2} \mathrm{O}\right) / 16 \mathrm{~g}$ of $\mathrm{N}$, while contribution of Lys and Met from microbial protein was calculated as: $332 \mathrm{mg}$ of Lys (excl. $\mathrm{H}_{2} \mathrm{O}$ ) per gram of microbial $\mathrm{N}$ and $95 \mathrm{mg}$ of Met (excl. $\mathrm{H}_{2} \mathrm{O}$ ) per gram of microbial N, respectively. The supply of intestinally absorbable Lys and Met from the preparations of rumen protected AA were calculated based on rumen degradability and intestinal digestibility of 0.9 .

Content of digestible energy and $\mathrm{NE}_{\mathrm{L}}$ in concentrate mixtures and roughages were calculated based on the corrected in vitro digestibilities of $\mathrm{OM}$ and the calculated amounts of digested crude fat, $\mathrm{CP}$, and carbohydrates as described by Weisbjerg and Hvelplund (1993). Content of metabolizable energy (ME) in individual feed components was estimated from in vitro digestibilities and chemical composition according to AFRC (1993).

Energy corrected milk (ECM) containing $3.14 \mathrm{MJ} / \mathrm{kg}$ was calculated from the determined concentrations of fat and protein in milk:

$$
\begin{gathered}
\mathrm{ECM}=\text { milk yield }(\mathrm{kg}) \times\{[0.383 \times(\text { fat } \%)+0.242 \\
\times(\text { protein \% })+0.7832] / 3.14\}
\end{gathered}
$$

The efficiency of utilization of AAT for milk protein synthesis $\left(\mathbf{k}_{\text {AAT }}\right)$ was calculated, estimating maintenance requirement as $3.25 \mathrm{~g}$ AAT $\times \mathrm{BW}^{0.75}$ (Madsen et al., 1995), net protein content in $1 \mathrm{~kg}$ of $\mathrm{BW}$ gain equivalent to $233 \mathrm{~g}$ of $\mathrm{AAT}$, and $\mathrm{BW}$ loss equivalent to $138 \mathrm{~g}$ of AAT based on figures from AFRC (1993). The efficiency of utilization of calculated ME for lactation $\left(\mathbf{k}_{\mathbf{l}}\right)$ was based on maintenance requirement of $0.41 \mathrm{MJ}$ $\times \mathrm{BW}^{0.75}$ (AFRC, 1993), assigning an energetic value of $17.3 \mathrm{MJ} / \mathrm{kg}$ of BW gain and $20.9 \mathrm{MJ} / \mathrm{kg}$ of BW loss (Gibb et al., 1992).

\section{Statistical Analysis}

Data were statistically analyzed independently for Lys and Met groups, as two continuous, completely randomized block designs, incorporating the effects of postruminal AA level, feed, and interaction between feed 
Table 5. Effect of level of Lys on plasma hormone and metabolite concentrations. Treatments were: low Lys concentrate and grass silage (LLG), high Lys concentrate and grass silage (HLG), low Lys concentrate and corn silage (LLM), and high Lys concentrate and corn silage (HLM).

\begin{tabular}{lcccccccc}
\hline & & & & & & \multicolumn{3}{c}{ Type II SS $P>F$} \\
\cline { 6 - 9 } & & & & & & & & Feed \\
& LLG & HLG & LLM & HLM & RMSE $^{1}$ & Feed & Level & $\times$ Level \\
\hline First half of trial & & & & & & & & \\
$\quad$ Insulin, (pmol/L) & 53 & 42 & 62 & 48 & 22.3 & NS & NS & NS \\
IGF-I, (ng/ml) & 91 & 94 & 108 & 94 & 20.5 & NS & NS & NS \\
bST, (ng/ml) & 2.19 & 3.17 & 1.93 & 2.62 & 1.97 & NS & NS & NS \\
Second half of trial & & & & & & & & \\
Insulin, (pmol/l) & 62 & 53 & 119 & 95 & 54.3 & 0.02 & NS & NS \\
IGF-I, (ng/ml) & 97 & 98 & 133 & 139 & 18.9 & $<0.001$ & NS & NS \\
bST, (ng/ml) & 1.65 & 2.16 & 1.71 & 2.42 & 1.75 & NS & NS & NS \\
Glucose, mmol/L & 3.7 & 3.7 & 3.6 & 3.7 & 0.39 & NS & NS & NS \\
NEFA, meq/L & 0.16 & 0.17 & 0.19 & 0.17 & 0.04 & NS & NS & NS \\
Urea, mmol/L & 7.3 & 6.9 & 9.0 & 9.8 & 0.99 & $<0.001$ & NS & 0.10 \\
\hline
\end{tabular}

${ }^{1}$ RMSE: Residual mean square error.

and AA level. This approach was chosen because interactions between Lys and Met were considered nonrelevant, as concentrate mixtures used for Lys and Met rations, respectively, were not comparable. The corresponding pretrial variable was used as a covariate in the analysis of milk production, milk composition, metabolite concentrations in plasma, and hormone concentrations in plasma. All milk and BW parameters were analyzed as means obtained over the entire experimental period using PROC GLM (SAS, 1990). The statistical model used was:

$$
\mathrm{Y}_{\mathrm{ijkl}}=\mu+\alpha_{\mathrm{i}}+\beta_{\mathrm{j}}+\gamma_{\mathrm{k}}+\delta_{\mathrm{jk}}+\zeta \mathbf{x}_{\mathrm{ijkl}}+\varepsilon_{\mathrm{ijkl}},
$$

where: $\mathrm{Y}_{\mathrm{ijk}}$ is the dependent variable, $\mu$ was the overall mean, $\alpha$ was effect of block ( $\mathrm{i}=1,2,3,4,5,6,7$, and $8), \beta$ was effect of ration ( $\mathrm{j}=$ grass silage and corn silage), $\gamma$ was the effect of AA level ( $\mathrm{k}=$ low or high), $\delta$ is the interaction between ration type and AA level, $\zeta$ was the corresponding pretrial covariate, and $\varepsilon=\mathrm{N}\left(0, \sigma^{2}\right)$ was the random variation which was assumed normally distributed with a variance $\sigma^{2}$ and a mean of zero. Results are reported as least squares means for each treatment combination together with the residual mean squares errors or standard error of the least squares means. Type II test was used to test main effects of ration type and AA level, thereby excluding the interaction term of the model when $F$-tests were made. Differences between least squares means were determined by conducting repeated $t$-tests, when significant main effects and interactions were observed. Partial correlation coefficients were calculated using the MANOVA procedure (SAS, 1990) either from a model including block and a covariate for the pre-treatment period (Table 3) or a complete model for the entire dataset $(n=64)$ containing all two- and three-way interactions (Table
4). Statistical significance was declared at $P<0.05$ and tendencies were considered at $P<0.10$.

\section{RESULTS}

\section{Intakes, Weight Changes, Milk Production, and Composition}

The intake of roughage differed significantly between corn and grass silage rations as did yield of ECM. The DMI of corn silage and hay varied from 4.8 to $7.5 \mathrm{~kg} /$ $\mathrm{d}$, and grass silage DMI varied from 6.5 to $9.5 \mathrm{~kg} / \mathrm{d}$. Concentrate DMI was stable at 11.3 to $11.5 \mathrm{~kg} / \mathrm{d}$ for treatments involving Lys supplementation and 9.8 to $10.0 \mathrm{~kg} / \mathrm{d}$ for treatments involving Met supplementation. The actual DMI resulted in an increased amount of intestinally absorbable Lys of 14 and $15 \mathrm{~g} / \mathrm{d}$ corresponding to 13 and 15\% increases in Lys supply on supplemented grass- and corn silage-based rations, respectively. Intestinally absorbable Met supply was similarly increased by 9 and $10 \mathrm{~g} / \mathrm{d}$, corresponding to 25 and $31 \%$ increases on supplemented grass- and corn silage-based rations, respectively. Alterations in postruminal Lys level did not result in significant changes in milk output or daily gain. There was, however, a significant effect of postruminal Met supply on milk fat content and milk protein content. No significant interactions were observed between feeds and postruminal Lys or Met supply (Tables 3 and 4), except for intestinal Met and Lys supply expressed as a percentage of total AA absorbed in the intestine (Table 4).

\section{Utilization of Energy and Protein}

When increasing the postruminal Lys supply, efficiencies of utilization of AAT for milk protein synthesis rose from 0.71 and 0.73 in the unsupplemented rations 
Table 6. Effect of level of Met on plasma hormone and metabolite concentrations. Treatments were: low Met concentrate and grass silage (LMG), high Met concentrate and grass silage (HMG), low Met concentrate and corn silage (LMM), and high Met concentrate and corn silage (HMM).

\begin{tabular}{|c|c|c|c|c|c|c|c|c|}
\hline & \multirow[b]{2}{*}{ LMG } & \multirow[b]{2}{*}{ HMG } & \multirow[b]{2}{*}{ LMM } & \multirow[b]{2}{*}{ HMM } & \multirow[b]{2}{*}{$\mathrm{RMSE}^{1}$} & \multicolumn{3}{|c|}{ Type II SS $P>F$} \\
\hline & & & & & & Feed & Level & $\begin{array}{l}\text { Feed } \\
\times \text { level }\end{array}$ \\
\hline \multicolumn{9}{|l|}{ First half of trial } \\
\hline Insulin, (pmol/L) & 69 & 55 & 53 & 36 & 35.4 & NS & NS & NS \\
\hline IGF-I, (ng/ml) & 80 & 79 & 89 & 88 & 14.4 & 0.10 & NS & NS \\
\hline bST, (ng/ml) & 2.47 & 2.99 & 3.67 & 3.63 & 1.10 & 0.07 & NS & NS \\
\hline \multicolumn{9}{|l|}{ Second half of trial } \\
\hline Insulin, (pmol/L) & 81 & 45 & 54 & 74 & 30.3 & NS & NS & 0.02 \\
\hline IGF-I, (ng/ml) & 93 & 90 & 123 & 111 & 16.3 & $<0.001$ & NS & NS \\
\hline bST, (ng/ml) & 2.03 & 3.02 & 0.61 & 1.77 & 1.44 & $\mathrm{NS}$ & NS & NS \\
\hline Glucose, mmol/L & 3.8 & 3.6 & 3.4 & 3.5 & 0.24 & 0.02 & NS & 0.06 \\
\hline NEFA, meq/L & 0.15 & 0.16 & 0.15 & 0.16 & 0.02 & NS & NS & NS \\
\hline Urea, $\mathrm{mmol} / \mathrm{L}$ & 8.0 & 7.3 & 9.6 & 10.0 & 1.77 & 0.006 & $\mathrm{NS}$ & NS \\
\hline
\end{tabular}

${ }^{1}$ RMSE: Residual mean square error.

to 0.74 and 0.78 (SEM $0.03 ; \mathrm{n}=8)$ in the supplemented rations, for grass silage- and corn silage-based rations, respectively. When manipulating postruminal Met supply, efficiencies of utilization of AAT for milk protein synthesis were 0.76 and 0.70 in the unsupplemented rations and 0.79 and 0.75 (SEM $0.02 ; \mathrm{n}=8$ ) in the supplemented rations based on grass silage and corn silage, respectively. The calculated efficiency of utilization of ME for lactation $\mathrm{k}_{1}$ was 0.55 and 0.57 for the low Lys treatments and 0.55 and 0.61 (SEM 0.02; $\mathrm{n}=$ 8 ) for the supplemented rations for grass silage- and corn silage-based rations, respectively. For the low Met treatments, $\mathrm{k}_{1}$ was 0.57 and 0.59 and was 0.59 and 0.63 (SEM $0.02 ; \mathrm{n}=8$ ) with the supplemented diets for grass silage- and corn silage-based rations, respectively. Neither the effects observed on the efficiency of utilization of absorbed AA for milk protein synthesis in response to altered Lys $(P=0.16)$ or Met $(P=0.08)$, nor the effects on the efficiency of use of ME for lactation observed for increased postruminal Lys $(P=0.36)$ or Met $(P=0.12)$ were statistically significant.

\section{Plasma Hormones and Metabolites}

Within the treatments that involved manipulation of Lys supply (Table 5), a significant effect of basal ration was observed on plasma concentration of IGF-I, insulin and urea, resulting in higher concentrations on the rations based on corn silage. Within the treatments involving Met manipulation (Table 6), the corn silagebased rations were also characterized by higher IGF-I and urea levels, together with decreased glucose levels and a tendency towards higher plasma bST concentration in the first half of the experiment. Analysis of residual correlations obtained from a model containing the effects of block and the appropriate pretrial covariate are shown in Table 7. The residual correlation coefficient identifies relations between variables that are mainly caused by the experimental treatments. Significant negative residual correlation coefficients were observed between ECM yield and plasma concentrations of insulin, IGF-I and NEFA. No significant residual correlations were observed between BW gain and plasma hormones or metabolite concentrations. Residual correlation coefficients obtained with a model containing all treatment effects, including two- and threeway interactions, thus, adjusting data with the complete model, are given in Table 8. These correlations demonstrate relations of a more general character, i.e., not attributable to the experimental treatments per se. Even after correction for effects attributable to the treatments, a negative correlation between ECM yield and plasma IGF-I concentration was still evident, while correlations between ECM yield and plasma levels of insulin or NEFA only tended to be significant. Plasma concentration of bST was negatively correlated to BW change, while no other significant correlations were observed between BW change and plasma concentrations of hormones and metabolites. The plasma concentrations of IGF-I were correlated $(r=0.11 ; P=0.01)$ to the plasma insulin concentrations but not to bST.

\section{DISCUSSION}

\section{Intakes, Weight Changes, Milk Production, and Composition}

All diets had an AAT to energy ratio, where further increases in milk yield would not be expected from increasing the AAT supply (Aaes et al., 1991; Misciattelli et al., 1999a). Supplementation with protected Lys or Met only resulted in modest increases in milk protein yields varying from 14 to $44 \mathrm{~g}$ per d $(P=0.36$ and $P=$ 
Table 7. Residual correlation coefficients $(r)$ between yield of energy corrected milk (ECM) or BW change and plasma concentrations of hormones or metabolites after adjusting data for the effects of block and pretrial ECM yield or BW.

\begin{tabular}{|c|c|c|c|c|c|c|}
\hline & \multicolumn{2}{|c|}{ Milk yield (kg ECM/d) } & \multirow[b]{2}{*}{$d f^{1}$} & \multicolumn{2}{|c|}{ BW change $(\mathrm{kg} / \mathrm{d})$} & \multirow[b]{2}{*}{$\mathrm{df}^{1}$} \\
\hline & $r$ & $P$ & & $r$ & $P$ & \\
\hline Insulin, $\mathrm{pmol} / \mathrm{l}$ & -0.35 & 0.009 & 55 & -0.05 & NS & 46 \\
\hline IGF-I, ng/ml & -0.62 & $<0.001$ & 55 & -0.02 & NS & 46 \\
\hline bST, ng/ml & 0.09 & NS & 45 & -0.17 & NS & $37^{\mathrm{a}}$ \\
\hline Glucose, $\mathrm{mmol} / \mathrm{l}$ & -0.13 & NS & 55 & -0.07 & NS & 46 \\
\hline NEFA, meq/l & -0.33 & 0.01 & 55 & -0.15 & NS & 46 \\
\hline Urea, mmol// & -0.23 & 0.08 & 55 & -0.18 & NS & 46 \\
\hline
\end{tabular}

${ }^{1}$ Degrees of freedom from the MANOVA analysis.

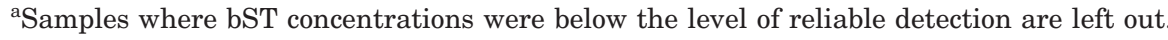

0.33 for Lys and Met supplementation, respectively), but the numerical increases were of the same magnitude as predicted from published response curves (Rulquin et al., 1993) and has been depicted together in Figure 1. The treatments designed to be low in intestinally absorbable Lys were based mainly on rape seed cake and secondly on undegradable corn gluten meal protein. In experiments where corn protein has been the major source of RUP, responses to Lys supplementation have often been observed (King et al., 1991; Schwab et al., 1992). In the present experiment, the Lys-deficient rations were, to a large extent, based on RUP from rape seed cake (56 g Lys/16 g N), which compared to corn gluten meal (17 g Lys/16 g N), contains a much larger proportion of Lys. The extent of Lys limitation could, thus, have been marginal in the present experiment. Furthermore, the actual increases in Lys supply from the basal to the supplemented rations amounted to only 13 and $15 \%$, which could have been too marginal an increase to detect a production response. The Met deficient rations were mainly based on RUP from soybean meal or protected soybean meal in the form of soypass (Borregård Lignotech, Sarpsborg, Norway) and to a minor extent from peas. Amino acid analysis revealed that

Table 8. Residual correlation coefficients $(r)$ between yield of energy corrected milk (ECM), BW change, and plasma concentrations of hormones and metabolites, after adjusting data for all effects, twoway and three-way interactions.

\begin{tabular}{|c|c|c|c|c|c|}
\hline & \multicolumn{2}{|c|}{ Milk yield (kg ECM/d) } & \multicolumn{2}{|c|}{ BW change $(\mathrm{kg} / \mathrm{d})$} & \multirow[b]{2}{*}{$\mathrm{df}^{1}$} \\
\hline & $r$ & $P$ & $r$ & $P$ & \\
\hline Insuli & -0.26 & 0.07 & 0.002 & NS & 48 \\
\hline IGF-I, ng/ml & -0.44 & 0.002 & 0.03 & NS & 4 \\
\hline $\mathrm{bST}, \mathrm{ng} / \mathrm{ml}$ & -0.02 & NS & -0.33 & 0.07 & $31^{\mathrm{a}}$ \\
\hline Glucose, mmol/l & -0.17 & NS & -0.19 & NS & 48 \\
\hline NEFA, meq/l & -0.26 & 0.07 & -0.10 & NS & 48 \\
\hline Urea, $\mathrm{mmol} / \mathrm{l}$ & 0.06 & NS & -0.05 & NS & 48 \\
\hline
\end{tabular}

${ }^{1}$ Degrees of freedom from the MANOVA analysis.

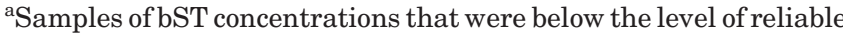
detection are left out. the protected soybean meal had a lower Met content than the normal soybean meal, but the unsupplemented grass silage-based rations resulted only in marginally lower levels of calculated intestinally absorbed Met than the corn silage-based ration, where Soypass was included only in small proportions. Responses to Met supplementation have been observed, mainly when the principal protein source was soybean (Robert et al., 1996; Armentano et al., 1997), and responses observed in the present experiment were within the levels observed earlier.

\section{Utilization of Energy and Protein}

The observed efficiencies of ME utilization for lactation were lower in all instances than those calculated according to AFRC (1993). Supplementation with rumen-protected AA resulted in a decrease in intake of $\mathrm{ME}$, resulting in differences of ME intake from 2 to 9 $\mathrm{MJ} / \mathrm{d}$ compared with the basal rations. Increased protein yields occurred despite a decreased energy intake. Differences in metabolizability $\left(\mathrm{q}_{\mathrm{m}}=[\mathrm{ME}] /[\mathrm{GE}]\right)$ between supplemented and basal diets, due to different roughage intakes, could not explain the differences in $\mathrm{k}_{1}$. Imposing corrections for decreasing ME availability at increasing feeding levels according to AFRC (1993) still confirmed the observed differences in $\mathrm{k}_{\mathrm{l}}$. The $\mathrm{k}_{\mathrm{AAT}}$ varied from 0.70 to 0.79 and was consistently but nonsignificantly higher for treatments with increased postruminal Lys or Met flow. The efficiency of utilization of absorbed AA for lactation varies between 0.64 and 0.80 in the modern protein evaluations systems (Hvelplund and Madsen, 1995), and the observed $\mathrm{k}_{\mathrm{AAT}}$ are, thus, within that range. The British metabolizable protein (MP) system (AFRC, 1993) operates with an efficiency of utilization of an "ideal" AA mixture $\left(\mathbf{k}_{\text {aai }}\right)$ of 0.85 and a relative value $(\mathbf{R V})$ of 0.8 to scale the $\mathrm{k}_{\mathrm{aai}}$ to arrive at efficiencies for MP utilization for lactation of 0.68 . The RV varies according to the tissues specific AA requirements, but only one working value is used 

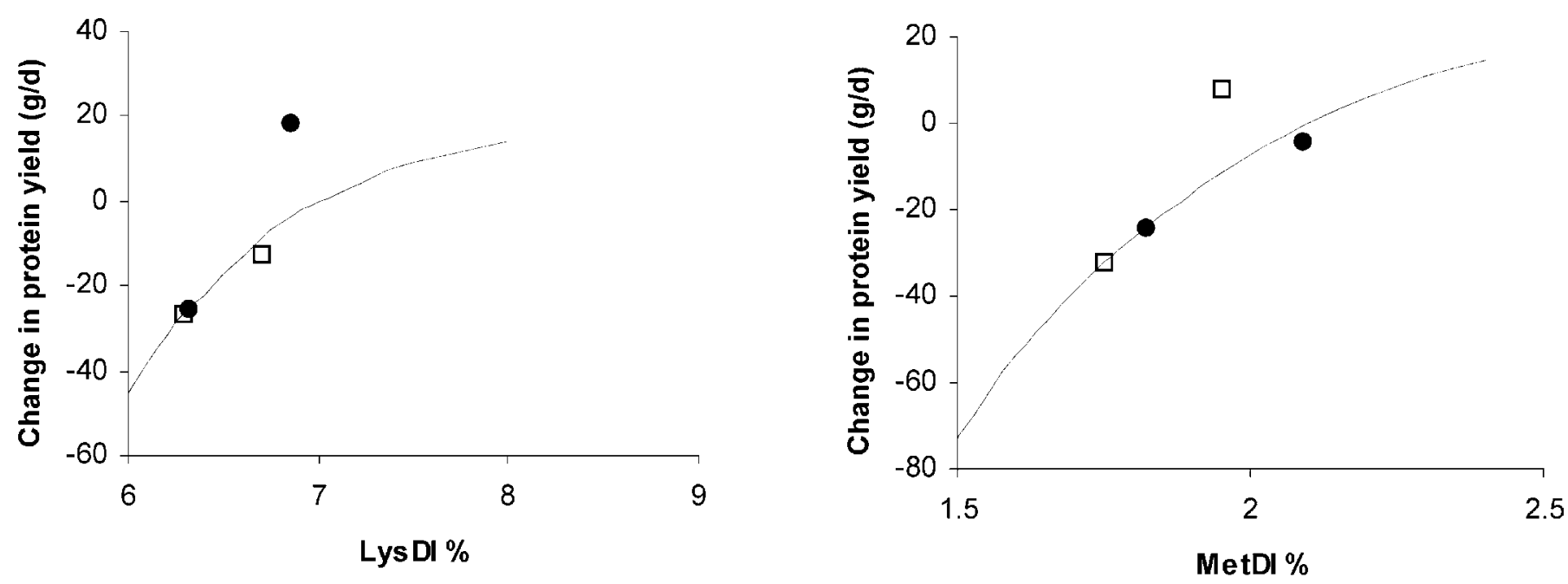

Figure 1a and 1b. Observed changes in milk protein yield in response to alterations in a) proportion of lysine in intestinally absorbable protein (LysDI\%) and b) proportion of methionine in intestinally absorbable protein (MetDI\%). Grass silage-based rations ( $)$, Corn silage based rations ( $\square$ ), Response curves to alterations in intestinally absorbable lysine or methionine according to Rulquin et al. (1993) (—). Axis of abscissa and ordinate axis does not intercept at zero.

in practice. The fact that the utilization of intestinally absorbed protein varies according to the absorbed AA profile has been demonstrated in trials with postruminal and isonitrogenous infusion of different protein sources (Rogers et al., 1984; Choung and Chamberlain, 1993). Improved $k_{A A T}$ should, thus, be observed when supplementing a limiting $\mathrm{AA}$, and the responses observed support this, although without statistical significance.

\section{Plasma Hormones and Metabolites}

The plasma hormone concentrations demonstrated a large variability, probably due to the large differences in DMI between animals, and the calculated LS-means for the treatments had considerable error terms associated. Lys and Met are not potent stimulators of bST, and insulin secretion in ruminants compared to other AA (Kuhara et al., 1991). While positive effects on plasma insulin levels have been observed in response to rumen-protected Met in the study of Blum et al. (1999), no significant effect of Lys or Met supplementation were observed on plasma insulin and bST levels in the present study. Plasma concentrations of IGF-I are dependent on nutritional status in growing (Breier, 1999) and lactating ruminants (Spicer et al., 1990; McGuire et al., 1992), but manipulating the nutritional status of lactating cows by dietary means or postruminal protein infusion has often failed to demonstrate alterations in levels of circulating IGF-I- and IGF-binding proteins, $-2,-3$, and -4 (Spicer et al., 1991; McGuire, 1992; Mackle et al., 1999). It has been speculated that this lack of effect could be due to an effect of protein per se and due to the interactions between energy and protein in the rumen. In lactating cows, positive energy balance is associated with elevated levels of IGF-I in plasma (Spicer et al., 1990), while feed deprivation has been demonstrated to decrease plasma IGF-I levels and proportional distribution of IGF-I-binding proteins (McGuire et al., 1998). In the present study, no significant correlations were observed between energy intake or protein to energy level and plasma hormone and metabolite concentrations. But ANOVA resulted in significant effects of feed on plasma IGF-I levels, with higher IGF-I levels observed at the low energy intakes, which were also characterized by an increased proportion of AAT per unit of $\mathrm{NE}_{\mathrm{L}}$. Additionally a relatively strong negative correlation was observed between yield of energy corrected milk and plasma IGF-I concentration and, thus, emphasizes that the effect of IGF-I on lactation cannot be estimated only by the level of circulating IGF-I but also need to include the distribution of IGF-I on its different binding proteins. However, this was not measured in the present experiment. Highyielding dairy cows in early lactation would normally have higher plasma levels of bST than lower yielding animals (Cowie et al., 1980), but no correlations between milk yield and bST was observed in the present study. The episodic release of bST requires frequent sampling over time, which was not done in the present study; however, the large number of cows per treatment is believed to counterbalance this. Indeed a positive relationship between weight loss and plasma bST level was detected, which is in accordance with observa- 
tions of increased plasma bST levels in feed restricted ruminants (McGuire et al., 1998; Breier, 1999). Plasma urea concentrations were not suppressed when the theoretical AA deficiency was alleviated by administration of rumen protected Lys or Met. The large differences in roughage intake within treatment groups had resulted in a substantial difference in the surplus of rumen degradable protein (PBV), especially on the corn silage-based rations. A small improvement in utilization of absorbed AA for productive purposes would, thus, be masked by the increased absorption of $\mathrm{NH}_{3}$ $\mathrm{N}$ over the rumen epithelium and the subsequently increased hepatic urea synthesis on the same treatments, thereby explaining the lack of reduction in plasma urea levels. Blum et al. (1999) observed a decrease in plasma NEFA concentration in response to rumen-protected Met, but in the present study no effects were observed on plasma NEFA, which exhibited a substantially larger variation than in the study of Blum et al. (1999).

\section{CONCLUSIONS}

A 25 to $31 \%$ increase in postruminal Met flows resulted in significantly increased protein and fat percentages in the milk, while 13 to $15 \%$ increases in postruminal Lys flow did not result in significant changes. The tendencies towards increases in milk protein yield occurred despite decreases in ME intake and a high protein to energy ratio, indicating an improved efficiency of utilization of absorbed AA and ME for milk production when increasing postruminal supply of Lys or Met. Even when rations were deliberately formulated to be theoretically deficient in intestinally absorbable Lys or Met, responses to supplementation with protected Lys or Met were marginal, thus indicating a need to also focus on AA other than Lys and Met as potential first limiting AA in future research. Effects of different postruminal levels of Lys and Met should also be studied at lower levels of total AA provision, especially to estimate the potential of reducing urinary nitrogen excretion from dairy cows. Tissue mobilization was correlated with high plasma bST concentrations. High milk yield was correlated with low plasma IGF-I concentrations and partially with low plasma NEFA and insulin levels. These parameters were mainly influenced by type of basal ration, while alterations in Lys or Met levels seemed to have no significant effect.

\section{ACKNOWLEDGMENTS}

We thank Janne Adamsen, J. Clausen, L. Gildbjerg, Hanne Pedersen, Edith Olsen, Hanne M. Purup, and E. Serup for their skilled assistance with the animal work and in the laboratory. I. Svensen (Novo Nordisk A/S, Bagsværd, Denmark) is acknowledged for supplying the IGF-I antibodies for the IGF-I assay. Rhône Poulenc Animal Nutrition, Antony, France is acknowledged for supplying rumen-protected AA and for examination of the concentrate mixtures. L. Misciattelli acknowledges receiving a scholarship from the Royal Veterinary and Agricultural University, Copenhagen.

\section{REFERENCES}

Aaes, O., V. F. Kristensen, and P. E. Andersen. 1991. AAT-niveauets indflydelse på mælkeydelsen ved forskellige energiniveauer. 703 . Beretning. Statens Husdyrbrugsforsøg, Foulum, Denmark.

AFRC. 1993. Energy and protein requirements of ruminants. CAB International, Wallingford, UK.

Armentano, L. E., S. J. Bertics, and G. A. Ducharme. 1997. Responses of lactating cows methionine, or methionine plus lysine added to high protein diets based on alfalfa and heated soyabeans. J. Dairy Sci. 80:1194-1199.

Association of Official Analytical Chemists. 1990. Official Methods of Analysis. AOAC, Arlington, VA.

Bayer. 1996a. SERA-PAK Glucose, Reagent kit for in vitro diagnostic use for the determination of glucose in serum and plasma. Publication No. TL9-6883K96. Bayer Corporation, Tarrytown, NY.

Bayer. 1996b. SERA-PAK Urea, Reagent kit for in vitro diagnostic use for the determination of urea in serum, plasma, and urine. Publication No. TL9-6891J96. Bayer Corporation, Tarrytown, NY.

Bech-Andersen, S. 1991. Determination of tryptophan with HPLC after alkaline hydrolysis in autoclave using $\alpha$-methyl-tryptohan as internal standard. Acta Agric. Scand. 41:305-309.

Blum, J. W., R. M. Bruckmaier, and F. Jans. 1999. Rumen-protected methionine fed to dairy cows: bioavailability and effects on plasma amino acid pattern and plasma metabolite and insulin concentrations. J. Dairy Sci. 2:1991-1998.

Breier, B. H. 1999. Regulation of protein and energy metabolism by the somatotropic axis. Domest. Anim. Endocrinol. 17:209-218.

Bruckental, I., I. Ascarelli, B. Yosif, and E. Alumot. 1991. Effect of duodenal proline infusion on milk production and composition in dairy cows. Anim. Prod. 53:299-303.

Choung, J. J., and D. G. Chamberlain. 1993. The effects of abomasal infusions of casein or soya-bean-protein isolate on the milk production of dairy cows in mid-lactation. Br. J. Nutr. 69:103-115.

Cowie, A. T., I. A. Forsyth, and I. C. Hart. 1980. Lactation. Pages 146-229 in Hormonal Control of Lactation. Springer-Verlag. Berlin, Germany.

Frystyk, J., B. Dinesen, and H. Ørskov. 1995. Non-competitive timeresolved immunofluorometric assay for determination of human insulin like growth factor I and II. Growth Regulation 5:169-176.

Gibb, M. J., W. E. Ivings, M. S. Dhanoa, and J. D. Sutton. 1992. Changes in body components of autumn-calving HolsteinFriesian cows over the first 9 weeks of lactation. Anim. Prod. 55:339-360.

Hvelplund, T., and J. Madsen. 1985. Amino acid passage to the small intestine in dairy cows compared with estimates of microbial protein and undegraded dietary protein from analysis on the feed. Acta Agric. Scand. 25(Suppl.):21-36.

Hvelplund, T., and J. Madsen. 1995. Protein utilization in ruminants. Pages 83-93 in Protein metabolism and nutrition. Proc. 7th Int. Symp. EAAP Publ. No. 81. Estacao Zootecnica Nacional, Santarem, Portugal.

Hvelplund, T., and M. R. Weisbjerg. 2000. In situ techniques for the estimation of protein degradability and postrumen availability. Pages 233-258 in Forage Evaluation in Ruminant Nutrition. CABI Publishing, Wallingford, United Kingdom.

Iburg, M., and P. Lebzien. 2000. Requirements of lactating dairy cows for leucine and methionine at the duodenum. Livest. Prod. Sci. 62:155-168. 
Ingvartsen, K. L., L. Munksgaard, V. K. M. Nielsen, and L. J. Pedersen. 1999. Responses to repeated deprivation of lying down on feed intake, performance, and blood hormone concentration in growing bulls. Acta Agric. Scand., Sect. A, Anim. Sci. 49:260-265.

Jacobsen, E. E. 1981. Sukker og stivelse (LHK) - ny analysemetode. Beretning nr. 98, Inst. Biotechnology, Kolding, Denmark.

Kim, C. H., J. J. Choung, D. G. Chamberlain, C. H. Kim, and J. J Choung. 1999. Determination of the first-limiting amino acid for milk production in dairy cows consuming a diet of grass silage and a cereal-based supplement containing feather meal. J. Sci. Food. Agric. 79:1703-1708.

King, K. J., W. G. Bergen, C. J. Sniffen, A. L. Grant, D. B. Grieve, V. L. King, and N. K. Ames. 1991. An assessment of absorbable lysine requirements in lactating cows. J. Dairy Sci. 74:2530-2539.

Kuhara, T, S. Ikeda, A. Ohneda, and Y. Sasaki. 1991. Effects of intravenous infusion of 17 amino acids on the secretion of $\mathrm{GH}$, glucagon, and insulin in sheep. Am. J. Physiol. 260:E21-E26.

Løvendahl P., J. Adamsen, R. Lund, and P. Lind. 2000. Sensitive sandwich assay for the determination of bovine growth hormone in blood and milk. J. Dairy Sci. 83(Suppl. 1): 206.

Løvendahl, P., and H. M. Purup. 2002. Technical note: Time resolved fluoro-immunometric assay for intact insulin in livestock species. J. Anim. Sci. 80:191-195.

Mackle, T. R., D. A. Dwyer, and D. E. Bauman. 1999. Effects of branched chain amino acids and sodium caseinate on milk protein concentration and yield from dairy cows. J. Dairy Sci. 82:161-171.

Madsen, J., T. Hvelplund, M. R. Weisbjerg, J. Bertilsson, I. Olsson, R. Spörndly, O. M. Harsted, H. Volden, M. Tuori, T. Varvikko, P. Huhtanen, and B. L. Olafsson. 1995. The AAT-PBV protein evaluation system for ruminants, a revision. Nor. J. Agr. Sci. 19(Suppl.):5-37.

Mason, V. C., S. Bech-Andersen, and M. Rudemo. 1980. Hydrolysate preparation for amino acid determinations in feed constituents 8. Studies of oxidation conditions for streamlined procedures. Z. Tierphysiol., Tierernährg. u. Futtermittelkde. 43:146-164.

McGuire, M. A., J. L. Vicini, D. E. Bauman, and J. J. Veenhuizen. 1992. Insulin-like growth factors and binding proteins in ruminants and their nutritional regulation. J. Anim. Sci. 70:29012910.

McGuire, M. A., D. A Dwyer, D. E. Bauman, and D. F. Smith. 1998. Insulin-like growth factors in plasma and afferent mammary lymph of lactating cows deprived of feed or treated with bovine somatotropin. J. Dairy Sci. 81:950-957.

Misciattelli, L., T. Hvelplund, and M. R. Weisbjerg. 1999a. Isoglucogenic infusions of protein and propionic acid in dairy cows. Page 83 in Book of Abstracts, 8th Int. Symp. Protein Metabolism. and Nutr., Aberdeen, United Kingdom. (Abstr.).

Misciattelli, L., V. F. Kristensen, T. Hvelplund, and M. Vestergaard. 1999b. Behov for individuelle aminosyrer til mælkeproduktion. pages 49-65. in Intern rapport nr. 118. Danish Inst. Agric. Sci., Foulum, Denmark.

Misciattelli, L., V. F. Kristensen, T. Hvelplund, and M. R. Weisbjerg. 2001. Milk production, amino acid and energy utilization in response to increased postruminal lysine and methionine supply in dairy cows. Pages 389-392 in Energy Metabolism in Animals, Proc. of the 15th Symp. on Energy Metabolism in Animals. EAAP Publ. No. 13, Snekkersten, Denmark. (abstr.).

Misciattelli, L., T. Hvelplund, M. R. Weisbjerg, J. Madsen, J. Møller, R. Thøgersen, and A. M. Kjeldsen. 2002. Fodermidlernes indhold af aminosyrer og aminosyrernes andel af AAT. Rapport nr. 98. The Natl. Committee on Danish Cattle Husbandry, Skejby, Denmark.

Møller, E., P. E. Andersen, and N. Witt. 1989. En sammenligning af in vitro opløselighed og in vivo fordøjelighed af organisk stof $i$ grovfoder., 13. Beretning fra Fællesudvalget for statens Planteavls- og Husdyrbrugsforsøg, Lyngby, Denmark.

Robert, J. C., B. K. Sloan, and C. Denis. 1996. The effect of graded amounts of rumen-protected methionine on lactational responses in dairy cows. J. Dairy Sci. 79(Suppl. 1):256.

Robinson, P. H., W. Chalupa, C. J. Sniffen, W. E. Julien, H. Sato, T. Fujieda, K. Watanabe, and H. Suzuki. 1999. Influence of post ruminal supplementation of methionine and lysine, isoleucine, or all three amino acids on intake and chewing behavior, ruminal fermentation, and milk and milk component production. J. Anim. Sci. 77:2781-2792.

Rogers, J. A., J. H. Clark, T. R. Drendel, and G. C. Fahey. 1984. Milk production and nitrogen utilization by dairy cows infused post ruminally with sodium caseinate, soybean meal, or cottonseed meal. J. Dairy Sci. 67:1928-1935.

Rulquin, H., P. M. Pisulewski, R. Vérité, and J. Guinard. 1993. Milk production and composition as a function of post ruminal lysine and methionine supply: A nutrient-response approach. Livest. Prod. Sci. 37:69-90.

SAS/STAT ${ }^{\circledR}$ Users Guide, Volume 2, GLM-VARCOMP, Version 6, 4th Edition. 1990. SAS Inst., Inc., Cary, NC.

Schwab, C. G., C. K. Bozak, N. L. Whitehouse, and V. M. Olson, 1992. Amino acid limitation and flow to the duodenum at four stages of lactation. 2. Extent of lysine limitation. J. Dairy Sci. 75:3503-3518.

Spicer, L. J., W. B. Tucker, and G. D. Adams. 1990. Insulin-like growth factor-I in dairy cows: Relationships among energy balance, body condition, ovarian activity and estrous behavior. J. Dairy Sci. 73:929-937.

Spicer, L. J., W. J. Enright, M. G. Murphy, and J. F. Roche. 1991. Effect of dietary intake on concentrations of insulin-like growth factors-I in plasma and follicular fluid, and ovarian function in heifers. Domest. Anim. Endocrinol. 8:431-437.

Stoldt, W. 1952. Vorslag zur Vereinheitichung der Fettbestimmung in Lebensmitteln. Fette und Seifen 54:206-207.

Tecator, 1978. Determination of crude fibre in some feed and food samples by using the fibertec system and Weende method. Application note 01 . Tecator AB, Höganäs, Sverige. 4 pp.

Thomsen, K. V. 1979. Angivelse og beregning af fordøjeligt råprotein til kvæg og får. 269. Meddelelse, Natl. Inst. Anim. Sci., Copenhagen, Denmark.

Tilley, J. M. A., and A. Terry. 1963. A two-stage technique for the digestion of forages crops. J. Brit. Grassld. Soc. 18:104-111.

Vanhatalo, A., P. Huhtanen, V. Toivonen, and T. Varvikko. 1999. Response of dairy cows fed grass silage diets to abomasal infusions of histidine alone or in combination with methionine and lysine. J. Dairy Sci. 82:2674-2685.

Weisbjerg, M. R., T. Hvelplund, J. Frandsen, J. H. Frederiksen, and O. Aaes. 1991. Estimering af råfedtets fordøjelighed hos droøvtyggere baseret på fodermidlernes indhold af råfedt. 804. Meddelelse, Natl. Inst. Anim. Sci., Copenhagen, Denmark.

Weisbjerg, M. R., and T. Hvelplund. 1993. Bestemmelse af nettoenergiindhold $\left(\mathrm{FE}_{\mathrm{K}}\right)$ i foder til kvæg. Forskningsrapport Nr. 3. Natl. Inst. Anim. Sci., Foulum, Denmark. 